\title{
ON APPLIANCES FOR WORKING UNDER WATER, OR IN IRRESPIRABLE GASES.
}

By Me. W. A. GORMAN, of London.

History of Diving.-In bringing before the Members of this Institution the following paper, the author does not intend describing at any length the early history of diving.* From the earliest times divors have been employed in fishing for pearls, corals, and sponges, and have been accustomed, before descending, to place a piecs of sponge soaked in oil between their teeth. This is said to have enabled some of the most hardy to remain at least six minutes under water.

The records of the earlier attempts to provide some artificial supply of air to divers under water are unsatisfactory. Roger Bacon (A.D. 1240) was supposed to have originated a machine for working under water. The invention of the diving bell is generally assigned to the sixteenth century. The first account of its use in Europe is that of Tasnier, who relates that in 1538, at Toledo in Spain, he saw two Greeks, in the presence of Charles V., let themselves down under water in a large inverted kettle without being wet.

Lord Bacon, in his "Novum Organum" (A.D. 1600), describes the primitive method adopted in his time, in which there was no

* 'Those who take an interest in the subject are referred to Lord Bacon's "Novum Organum;" "Philosophical Transactions," from the time of Halley, 1678 ; "The History of Inventions," by Beckman; Boyle's "Experimental Plilosophy;" the article on Diving in "The Encyclopedia Britannica ;" and Messrs. Siebe and Gorman's book on "Diving." 
mode of replenishing the air in the inverted vessel, or bell, whilst under water. In 1632 Richard Norwood took out a patent for a special means to dive into the sea.

Borelli, in 1669, constructed a copper vessel two feet in diameter, with glass fixed before the face of the diver; this he termed a "Vesica." It was worn as a helmet, and securely attached to a dress of goatskin. Within the "Vesica" were pipes, by means of which a circulation of air was contrived. An air-pump was affixed to his side, by which the diver was said to condense or rarefy the air within the "Vesica," so as to make himself heavier or lighter, on the same principle as the air-bladder of fishes. Artificial webbing was also supplied to the feet, to enable him to tread the water.

In the latter part of the seventeenth century the diving bell came largely into use. About 1680 a mania arose for undertaking submarine exploration, and companies were formed for that purpose; but through imperfect appliances they were unable to reap profitable results.

About the year 1700 Dr. Edmund Halley devoted much time to subaqueous experiments, and in 1716 he read a paper before the Royal Society, entitled "The Art of Living under Water." In this paper he says, "When there has been occasion to continue long at the bottom of the sea, some have contrived double flexible pipes to circulate air down into a cavity, enclosing the diver with armour, to bear off the pressure of water, and give leave to his breast to dilate upon inspiration, the fresh air being forced down one of the pipes, with bellows, or otherwise, and returning by the other of them, not unlike an artery and vein. This has been found sufficient for small depths, 12 or 15 feet; but when the depth surpasses three fathoms, experience teaches us that this method becomes impracticable, for though the pipes and rest of the apparatus may be contrived to perform their office duly, yet the water, its weight being now become considerable, does so closely clasp the limbs that are bare, or covered with fiexible covering, that it obstructs the circulation."

To remedy these inconveniences he turned his attention to the diving bell. His contrivance consisted of a truncated cone of wood, $3 \mathrm{ft}$. diameter at the top, and $5 \mathrm{ft}$. at the bottom, and containing 60 
cubic ft. In the top was placed a strong glass to give light, and a cock to let out the vitiated air; the bell was coated with lead and weighted, that it might sink steadily; when below it was supplied with air by two barrels of $\mathbf{3 6}$ gallons each, which were alternately lowered and raised. He states that he remained one hour and thirty minutes under water, at a depth of 10 fathoms.

In 1721 he described to the Royal Society a method by which the diver could leave the bell. He used pipes, $40 \mathrm{ft}$. in length, made with spiral brass wire inside; one end being fixed in the bell, and the other to a cock which opened into the diver's cap. This was made of lead, weighing $56 \mathrm{lbs}$; and he also wore a girdle of the same weight, and clogs of lead woighing $12 \mathrm{lbs}$. each.

About the same date, 1716, when Dr. Halley read his first paper to the Royal Society, John Lethbridge invented an air reservoir, made of wainscot, perfectly round and $6 \mathrm{ft}$. long, $2 \mathrm{ft} .6 \mathrm{in}$. in diameter at the head, and $1 \mathrm{ft}$. 6 in. at the foot. $\mathrm{H}_{\theta}$ compressed air into this with $n$ pair of bellows, and then lowered it with himself under water, where he remained 34 minutes. Numerous inventors followed in his track.

Smeaton, in 1779 , first employed the diving bell for civil engineering operations, in repairing the bridge at Hexham, Northumberland. The apparatus was an oblong wooden box, $4 \mathrm{ft}$. high, $2 \mathrm{ft}$. wide, and $3 \mathrm{ft}$. 6 in. long. It was supplied with air by a pump fixed on the surface.

Soon after the construction of the New Dock at Ramsgate, in 1784, Smeaton employed an improved diving bell weighing half-a-ton : two men worked in it, and were provided with a constant supply of fresh air through flexible pipes, by means of a force pump placed in a lighter which floated over them. Smeaton appears to be the first person who used the air-pump to force a supply of fresh air to the fivers, in the bell under water.

A diving dress was invented in 1798 by Kleingert, of Breslau, which consisted of strong tin-plate armour, Fig. 1, Plate 22, in the form of a cylinder encasing the diver's head and body, with a leather jacket and strong leather drawers. These were made waterproof, and joined by brass hoops around the metal armour, so that the diver was relieved 
from the pressure of the water except on the legs and arms. $\mathrm{Hc}$ inhaled the air from the surface through one pipe, and the vitiated air was carried up to the surface by another. A diver could not with this apparatus descend to greater depths than $20 \mathrm{ft}$.

About the same date Messrs. John and William Braithwaite constructed a diving apparatus, with which they carried out several successful operations. In 1805 they recovered $£ 75,000$ in dollars from the East Indiaman Earl of Abergavenny.

Rennie, whilst occupied on the works of Ramsgate Harbour, in 1813 , made considerable improvements in the diving bell ; he designed and constructed a diving bell of cast-iron (Fig. 2, Plate 22), $6 \mathrm{ft}$. high, $4 \mathrm{ft} .6$ in. wide, and $6 \mathrm{ft}$. long, with one side a little heavier than the other, so that it should hang a little out of level, and thus more readily allow the vitiated air to escape. In the top of the bell six thick bull's-eyes of glass MII were fixed to admit light. In the centre of the top was a circular hole, in which a brass lining was firmly fixed. To the under side of this was attached the inlet air-valve $\mathbf{E}$, on a brass grating of the form shown in Fig. 3. The valve itself was simply a disc of strong leather. A nozzle $\mathrm{N}$ was fixed to the top of the bell above the valve, and to this was screwed a watertight leather hose $2 \frac{1}{2}$ in. diameter, connected to the air-pump, which was constantly worked by a sufficient number of men. Inside the top of the bell were strong lugs, to which were attached chains FF, Fig. 2, for suspending stones or other material. The bell was fitted with seats $B B$, and a rail $C$ for hanging the various tools used by the men. It was slung by stout chains $A$ from a double-purchase crab fixed on a truck, which could travel along the gantry; the total weight was five tons. Rennie used this diving bell with great success in the numerous harbour and other works with which he was associated.

The Open Diving Dress.--In the year 1828 or 1829 the late Mr. Augustus Siebe, A.I.C.E., the founder of the author's firm, was applied to by Messrs. Deane to assist them in the construction of a diving dress, afterwards known as the Open-Helmet Diving Dress. The helmet, Fig. 4, Plate 22, was made of copper, with a screw lens in front, and a metal elbow riveted on the back of the head-piece, to connect 
the air-pipe with the pumps, the head-piece and breast-plate being in one. To the breast-plate was attached a canvas jacket, which, with the aid of two lead weights, kept the helmet fixed upon the shoulders. Boots with lead soles, weighing $12 \mathrm{lbs}$. each, were worn, and also a waterproof dress fastened round the neck, over which were placed the helmet and jacket. The air escaped into the water from underneath the outer canvas jacket, and the water reached within a few inches of the diver's mouth, so that he had to work in a vertical position. The air-pumps had three cylinders, 3 in. diameter, 9 in. stroke. Even at the present day many of the const divers use this form of dress.

The, Close Diving Dress.-About 1839, when engaged at the wreck of the Royal George, Mr. Siebe, observing the danger attending the use of the open helmet, introduced his invention of the close helmet, Fig. 5, Plate 23, fitted with inlet and outlet valves, $I$ and $O$, and with a segmental neck screw, to remove the head-piece by one-eighth of a turn. The waterproof dress was fastened to the metal collar by screws and brass bands. Colonel Pasley, R.E., (afterwards MajorGeneral Sir C. Pasley) at once ordered the Royal Engineer divers to be equipped with this dress and helmet; and the operations at the wreck, owing to this great improvement, were carried on with much greater rapidity, and without accident.

The above brief deseription of diving apparatus in its primitive form will be sufficient to show the progress made up to a recent date.

Modern Apparatus. - This apparatus, as illustrated in Plates 24 and 25 , is a very perfect one, combining a high degree of safety with comfort for the diver. 'The air-pump, Plate 24, is eapable of compressing air to a pressure of $240 \mathrm{lbs}$. per sq. in., and consists of two vertical double-action gun-metal cylinders CC, securely fixed to a bed-plate of gun-metal, which is bolted on the base of two side standards AA, the whole forming a framing to carry the crank-shaft B. Each piston, Fig. 7, is constructed of two inverted cups of leather LL, having leather packing placed between, and the whole is secured by two cast-iron piston-plates MM fitted to tho piston-rod inside the leather cups, and pressed together by a nut. Grooves are formed in the 
periphery of the piston-plates, to contain expanding springs, which, pressing outwards against the inner side of the leather cups, keep them in close contact with the cylinder, and thus maintain the piston in a perfectly air-tight condition. Each cylinder cover has an oil tap for lubrication.

The piston-rods pass through glands $H$, packed with turned leather washers, and are extended so as to work in guides KK, Fig. 6. Double connecting slings SS, with gun-metal bearings, connect the piston-rods to the crank-pins. Inlet and outlet valves, $I$ and $O$, Fig. 7, are fixed in the cover of each cylinder, and also in the baseplate. Spindle valves are used, faced with leather, and having gunmetal seatings, to which the valve is kept by a spiral spring. The top and bottom outlet valves are connected by a passage cast on the cylinder, and leading to the air-delivery nozzle $N$. The cylinders are surrounded by a copper cooling cistern W, Fig. 6 .

Pressure gauges GG show the depth and pressure at which the diver is working, and are also used for testing the air pipes. Each gange is marked off to represent the pressure in pounds per sq. in. at given depths of water, as given by the following Table:-

\begin{tabular}{|c|c|c|c|}
\hline $\begin{array}{l}\text { Deptil } \\
\text { Iit. }\end{array}$ & $\begin{array}{c}\text { Pressure } \\
\text { 1bs. per sqg. in. }\end{array}$ & $\begin{array}{l}\text { Deptl } \\
\text { Ft. }\end{array}$ & $\begin{array}{c}\text { Pressure } \\
\text { lbs. per sq. in. }\end{array}$ \\
\hline 20 & $8 \cdot 68$ & 120 & 52.08 \\
\hline 30 & $13 \cdot 02$ & 130 & $56 \cdot 42$ \\
\hline 40 & $17 \cdot 36$ & $140^{*}$ & $60 \cdot 76$ \\
\hline 50 & $21 \cdot 70$ & 150 & $65 \cdot 10$ \\
\hline$c 0$ & $26 \cdot 04$ & 160 & $69 \cdot 44$ \\
\hline 70 & $30 \cdot 38$ & 170 & $73 \cdot 78$ \\
\hline 80 & $3 t \cdot 72$ & 180 & $78 \cdot 12$ \\
\hline 90 & $39 \cdot 06$ & 190 & $82 \cdot 46$ \\
\hline 100 & $43 \cdot 40$ & $204 \uparrow$ & $88 \cdot 54$ \\
\hline 110 & $47 \cdot 74$ & & \\
\hline
\end{tabular}

* Practical limit of diving.

$f$ The last figure is the greatest depth to which (to the autlor's knowlelge) a diver bas ever descended.

The fly-wheel and winch-handles, fitted on the crank-axle, aro 
made to be easily removed, and the whole pump is securely fitted in a strong teak case, Fig. 8, Plate 23.

The air-distributing arrangement, by which the air can be transmitted to one or two divers as occasion may require, is as follows. The two outlet nozzles, $A$ and $A_{1}$, Fig. 9, Plate 23 , are connected by a cross branch-pipe $B$, and a three-way cock $C$ is fixed at the junction of the pipe $B$ with the nozzle $A_{1}$. The position of this cock, when supplying air from both cylinders to one diver, is shown in Fig. 9, while Fig. 10 shows the position when two divers are to be supplied, each being in connection with one cylinder. If at any time the pump is supplying one diver, and it is desired to send down the second diver to his assistance, it is only necessary to turn the lever of the cock $\mathrm{C}$ round to the position marked "two divers," Fig. 11, and work the pump faster. The great advantage of this pump is that it can supply air to two divers independently at different depths. Two divers can work from it to a depth of $90 \mathrm{ft}$., or one alone to a much greater depth.

The improved helmet, Figs. 12 and 13, Plate 25, is made of tinned and planished copper, and consists of two parts, the breast-plate and the head-piece. The breast-plate is so constructed that the diver has free use of his arms, and can reach over the head-piece. It has a segmental neck ring $R$, so that the head-piece can be removed by one-eighth of a turn, and has a brass band $S$ at the bottom, with twelve screw studs, to which are fitted four brass plates, fastened by wing-nuts, thus forming the junction with the waterproof dress. $A$ is an air passage for conducting the air supply over each lens, so as to prevent the diver's breath from condensing upon the glass. $\mathbf{B}$ is a nozzle to which the air pipe is connected, and inside which is placed an inlet valve ; in case of accident to the air pipe the air pressure inside would close this valve, and thus prevent the water from entering the helmet. $D$ is the front lens, which can be unscrewed, so that the diver can converse without being undressed; and $\mathbf{E}$ is the side lens. $O$ is the outlet valve for the escape of vitiated air into the water. $G$ is a stud for securing the weights, and $H$ a regulating tap, by means of which the diver can regulate his supply of air without giving a signal. 
Fig. 14, Plate 25, shows a section of the outlet valve, which is placed at the right-hand side of the back of the helmet, and within reach of the diver: it is a metal cone valve, over which is screwed a metal cap C, with small holes drilled in it to allow the air to escape into the water. The valve spindle is kept in position by a hard-drawn copper-wire spring. There is a second brass cap J, screwed on the first one, and having a small opening. In this the diver can insert his finger, and press down the valve spindle, so as to confine the air, and thus inflate his dress and rise to the surface. The valve has a small metal chamber I, carried up a short distance, so that the opening into the helmet is four inches above the valve.

The waterproof dress is made of strong tanned twill, with an india-rubber lining between the thicknesses of the material. It has mineralised india-rubber collar and cuffs. The boots have lead soles weighing $14 \mathrm{lbs}$. each. At the front and back are lead weights $40 \mathrm{lbs}$. each. An air pipe with spiral wire embedded in it, and fitted with joints to connect up to any desired lengths; a knife, in watertight case, a leather belt and pipe holder, and a double suit of flannels, complete the equipment. For deep water the men wear a body guard, to keep off the pressure.

Experience in Working.-Some special cases of diving with this apparatus may be mentioned. In the recovery of treasure from the Hamilla Mitchell, sunk off Shanghai, in a depth of $144 \mathrm{ft}$., the diver, Robert Ridyard, worked for five consecutive days five to six hours

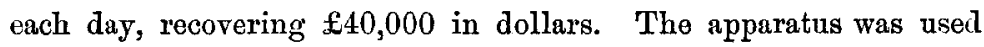
constantly day and night at the raising of the Eurydice; on an average eight divers were working together in a strong tide and amongst wreckage, but not a single accident occurred.

When the news reached England that H.M.S. Doterel was blown up, the Admiralty at once telegraphed to the ships of war on the station to proceed to the scene of the disaster, as each of H,M. ships carries a seaman diver and also an artificer diver.

H.M.S. Gannet was the first vessel to arrive at Sandy Point. Lieutenant Stanley Dear Pitt, R.N., volunteered to accompany George Hunt, artificer diver in making a careful survey of the wreck, 
which was lying in 12 fathoms of water; the result being positive proof that the boilers had not caused the explosion, as they were found in perfect condition. The author considers that the apparatus he has described was in this particular case of great service to the engineering world, to say nothing of the importance to the country, as the whole of the armament and other valuable property were recovered.

For engineering works the apparatus is in use at the present time to a considerable extent, at Colombo, Port Elizabeth, Madras, and many other harbours. The average number of hours for the divers to work in water, say to $60 \mathrm{ft}$. depth, is four. Their pay depends upon their capabilities; but in this country the average rate is $£ 410$ s. per week for masons, $£ 4$ for carpenters, and $£ 310 s$. for labourers. In wrecking operations the divers work at a salvage scale according to the depth, and as a rule earn very good wages.

As so many various handicrafts are required for submarine works, the author's firm have erected a diving tank in their factory, where men are trained, and also experiments carried out. The selection of divers requires much care. Steady habits are essential, and from long experience it is found that men of sanguineous temperament are unfit to bear great pressure, while a man slightly built but muscular, although he may seemingly be weak in lungs, often turns ont a first-class diver, and improves in health and strength. Among the many purposes for which the diver is required may be mentioned the following:- The repairs and inspection of dock gates, sluices, bridge foundations, \&c.; the removal of pumps and other appliances in shafts; the repair of well-pumps wheu under water; the cleaning of iron ships' bottoms, and repairing of leaks; the examining or repairing of fouled or damaged propellers, \&c.; the sinking of cylinders for piers and bridges; the laying of pipes for gas and water in rivers or harbours; torpedo service; and lastly, fishing for sponge, pearl, coral, and amber.

Appliances for Working in Irrespirable Gases. - The Fleuss apparatus represents a great improvement in this direction. It is self-contained and entirely independent of any communication with 
the outer atmosphere, thus enabling the wearer to breathe with safety in the most noxious gases, to walk any distance, and to explore the most intricate turnings of a mine with perfect freedom of action. The principle of the apparatus is that the wearer breathes the same air over and over again, the carbonic acid being absorbed from it after each expiration, and at the same time the requisite amount of oxygen restored to it; thus rendering it pure, and fit to be again inhaled in to the lungs.

The apparatus, Figs. 15 and 16, Plate 26, consists of a strong copper cylinder $\mathrm{D}, 6 \frac{1}{2}$ in. diameter, and $12 \mathrm{in.}$ long, with domed ends, and capable of containing $4 \mathrm{cub}$. ft. of oxygen, at 16 atmospheres pressure; this is sufficient for four hours' respiration. Above the cylinder D is attached a square metal box B, 12 in. $\times 12$ in. $\times 4$ in.; this contains the carbonic acid filter, which is a box of vulcanite divided into four compartments by vertical diaphragms, in such a manner. that the exhaled breath of the wearer is made to pass twice up and down through the vessel, before it is in a position to be again inhaled. This box is fitted with small cubes of india-rubber sponge, saturated with a thick pasty solution of caustic soda. The exhaled air, being finely divided as it passes through the interstices of the sponge, and coming in contact with a very extended surface of caustic alkali, becomes thoroughly cleansed of all the objectionable products of respiration.

As shown in Figs. 17 and 18, Plate 26, a flat bag G of vulcanised india-rubber, 12 in. $\times 15$ in., is strapped on in front of the wearer ; into this the exhaled air passes from the filter, by means of a tube $J$ of india-rubber. The bag is also in communication by the pipe $P$, Figs. 15 and 16, with the oxygen chamber $D$, and the supply of oxygen to the bag $G$ is regulated by a jamb screw-valve $T$, under the control of the wearer. This valve is also shown half size in Fig. 19. The mask A, Figs. 17 and 18, is made to fit air-tight to the face of the wearer, and is held in place by straps buckled at the back of the head. A band of rubber is made to cover the ears, and the eyes are protected by glass, when it is necessary to go into smoke or gases that would hurt them. The mask is provided with a pair of flexible trubes $E$ and I, with valves, the one for exhaling 
$\mathrm{E}$ being in communication with the filter $\mathrm{B}$, and the one for inhaling $\mathrm{I}$ being connected to the air bag.G. The slightest effort of inhalation brings the revivified air freely to the lungs of the wearer. The whole apparatus weighs $26 \mathrm{lbs}$, and can be adjusted in a few seconds.

The author considers this apparatus particularly adapted for use in coal mines, or when men have to deal with noxious gases. Mr. Fleuss has remained in the densest smoke, as also in a glass chamber charged with carbonic acid, for a considerable time. His apparatus was regularly used for some time at the Westminster Aquarium, and also more recently at the re-opening of the Maudlin seam of the Seaham colliery, after the fatal explosion of September 1880. The author has to thank Mr. Fleuss for his kind permission to bring his improvements before the notice of the Institution.

In conclusion the author may perhaps allude to the use of the Electric Light for submarine purposes. This is really the only light which can be of use to the diver, and of late the author has made some very satisfactory trials of it. The Telephone has not been fully tested in practice, the divers preferring their ordinary signal line, or communicating by a slate.

\section{Abstract of Discussion on Diving Appliances.}

Mr. Gorman exhibited a complete diving helmet, and other appliances. He wished to add that since the paper was written (now some months ago) Mr. Fleuss had had his apparatus in actual practice. Not long since he had saved ten lives in the Killingworth colliery; and he had also used his apparatus at the opening out of the Maudlin seam in the Seaham colliery. 
Mr. Henry A. Fuevss showed the action of the apparatus, Plate 26. He explained that the apparatus was put on, the mouth piece hung round the miner's neck by the elastic fastener, and the eye protector carried by putting the arm through the fastener; and in that condition he went into the pit. The eye protector and mouth piece could be adjusted in a moment in case he came suddenly into foul gases. (In Figs. 17 and 18 the mouth piece and eye protector aro combined in one, forming a mask.) By putting his hand behind him and turning the tap $T$, he could at any time get more air from the reservoir $\mathrm{D}$; and this had to be done every ten minutes. This air was pure oxygen admitted from the reservoir $D$ to the bag $G$, which held 300 or 400 cubic inches. He could if he chose make the man breathe only the proper mixture of oxygen and nitrogen, by first inflating the bag with exhaled breath, before connecting the breathing tubes, and by simply keeping up a constant supply of oxygen to take the place of that absorbed by the lungs and that abstracted in forming carbonic acid. But that was a dangerous practice; if the man got a considerably less amount of oxygen than was contained in the natural air he would drop insensible, and if not relieved would die. By tho arrangement he had explained everything was perfectly safe, because as long as there was any air in the bag it would contain sufficient oxygen; and whenever the man found the volume in the bag was not sufficient, he could put his hand to the tap and admit more. The proportion, he believed, was about one-third oxygen to two-thirds atmospheric air, or perhaps rather smaller. If common air were admitted to the bag instead of oxygen, under the same conditions as to absorbing the carbonic acid gas, the man would go on breathing a higher and higher percentage of nitrogen without knowing $i t$, and suddenly, when the oxygen was nearly gone, he would drop down insensible; but, in consequence of bejing able to continue inhaling a full breath, he would never feel the deficiency of oxygen until it was too late.

The carbonic acid remained of course in the filter, forming carbonate of soda, and the volume of gas thus abstracted was made up by the oxygen. He had made an improved filter, since the paper 
was written, in which, instead of india-rubber sponge, he was simply using tow, with caustic soda sticks. This formed an efficient filter; and when the soda was completely carbonised, the whole could be thrown away. The sponge cost a sovereign, but a halfpenny worth of tow was sufficient for the same purpose.

Mr. JEREMIAH HEAD asked what was the composition of the air that came back into the bag from the filter, and was used over again; and also what was the object of the short piece of pipe attached to the side of the eye protector.

Mr. Fuevss said the exhaled air contained less oxygen than when inhaled, the same nitrogen, and a comparatively large proportion of carbonic acid, of which the carbon was supplied from the lungs. The whole of the carbonic acid was absorbed by the filter; so that what came back to the bag was atmospheric air, minus a certain quantity of oxygen, a part of which remained in the filter in the form of carbonate of soda, while a small part was absorbed by the lungs. He lad used the apparatus, in actual work at the Seaham colliery, for an hour and a half at a time, and for experimental purposes much longer. The short piece of india-rubber tube on the eye protector was simply for inflating with the mouth the air-cushion in the eyeplate, in order just to make an air-tight joint for the face, whon working in foul gases which might injure the eyes.

Mr. Charles Cochrane said that, with regard to the application of diving apparatus generally to mining, he could bear testimony to the admirable and prompt way in which work could be carried out, even in the provinces. His firm recently lost a lift of trees in a colliery in South Staffordshire, and the only chance of preventing disaster was to get a diver at work at once. They lost the lift about four o'clock in the afternoon, and telegraphed at once to London for an apparatus to be brought down similar to that which had been described; and they were at work again on the following day, within twenty-four hours of the accident. 
Mr. Dnutet Halpin said he had used the author's diving apparatus with great success on several occasions, and could speak very highly of it, and also of the men who worked it; it was no use having the best apparatus in the world unless there were suitable men for working it. Of all workmen he would give the palm to divers for causing trouble, if they were not kept under proper control; but when they were under proper control a very good amount of work could be got out of them. There was one point with regard to the helmet that he thought might be improved. The glass shield in front had to be taken off when necessary to speak to the man, and then put on again. It was an awkward job at the best of times, and it was made more awkward by the buttons for unscrewing being solid knobs; if these were made like a common winch-handle, and then milled, they would give a chance of doing what was wanted, without doing what was not wanted, but sometimes happened, namely dropping the shield overboard.

Mr. Charles Hawrster said that some few years ago he had had occasion to repair a pump which had failed in a well of small diameter, put down temporarily to enable a larger shaft to be sunk at some waterworks in Lancashire. In that confined situation one of the parts of the pump gave way, and the only means of getting at it to do the necessary repairs was by means of divers. A diver was sent down by the author's firm, and although the well was crowded with pump trees and their means of support, he descended to a depth of $130 \mathrm{ft}$., and in that depth of water he successfully replaced the broken part; so that the pump was able to be set to work again with comparatively little delay. He had also employed divers very recently to assist in laying two lines of gas and water pipes across the harbour at Lowestoft. Those pipes were laid in a trench, that had been dredged in part by Mr. Langley's dredger described at the last meeting (Proc. 1882, p. 100). After the trench had been ascertained, by means of the divers, to be perfectly level, the pipes were lowered; and it was then necessary, in order to clear the harbour, to cut away all the tackle by which they had been lowered-the chains, blocks, \&c.- -and let it fall to the bottom of the harbour. A diver afterwards went 
down and recovered the whole of the tackle, and ascertained at the same time that the pipes had been properly laid.

With regard to the admirable invention of Mr. Fleuss, he might be permitted to refer to the paper which his friend Mr. Marten and himself had the honour of presenting to the Institution in 1877 (Proceedings, p. 314) on the means to be employed for preventing or alleviating accidents at mines. Certainly, had this apparatus been invented at that time, it would have found a place in the list of appliances which they deemed it desirable should be kept in readiness at collieries, or in some situations where they could be obtained for use in case of need. The author had not referred to the model exhibited of a diving bell, which had been manufactured by Messrs. Siebe and Gorman, and employed at Barbadoes.

Mr. Gorman said he had not meant to do more than show the model of the bell, as he hoped to give a subsequent paper on appliances for excavating under water and for the removal of sunken rocks. The bell had an air-lock with two doors or valves, made to slide backwards and forwards in grooves. There was also a regulating valve, so as to equalise the pressure between the lock and the top or bottom as required. The bell was mostly used for laying concrete blocks or removing quantities of rock. When the bell was lowered, the pressure of the air lept the water to within four inches of the bottom, or on level ground within half an inch of the bottom, the men working with water boots. They had made an arrangement of stuffing-boxes, to bring down a tube for working one of Ingersoll's rock drills at the bottom, so that the work was done quickly. When the blasting holes had been charged and tamped, a signal was given by means of a wire to a gong at the surface. The man in the barge then placed to his ear the small speaking tube, having a diaphragm of thin copper, and listened to the instructions of the divers which way to move the bell. The bell was then moved away, and the charge was fired; then the bell was brought back again, and the débris cleared away through the air-lock. There was also an arrangement by which the top of the chamber was filled with water 
for ballast; and by turning a valve this water could be expelled by the air pressure, so as to make the bell almost float.

The depth at which the bell generally worked was 30 feet; but rings could be put on the internal tube, so that it might be lengthened as required, when the depth varied. The diameter of the tube was $3 \frac{1}{2}$ feet, and that of the exterior chamber 14 feet. The bell was weighted at the bottom with cast-iron ballast, which could be removed, if required, through a man-hole. In each of the air-lock doors there was a lens, so as to let a certain amount of light down into the bell; but candles had also to be used.

He exhibited one of the electric lamps made for the Admiralty, for use under water in torpedo or other work; it was the only light of any use under water. It was a differential lamp, the whole apparatus being at the top, while if there was any leakage of water it would lie in the bottom. The lamp threw ont a very powerful light, equal to 1500 candles, and one could read print plainly within six feet from the lump; but beyond that distance the light was very much diffused and lost, and became only sufficient for the men to grope their way by. It must be understood he alluded to night work in clear water.

Mr. E. A. CowPER asked if the light attracted the fish very much. He enquired because he had proposed some time ago to fish with the electric light, having a small net below the lamp to haul up at intervals, and so catch the fish.

Mr. Gorman said he had had some letters from Norway upon the same subject, and there they proposed to use the electric light for that purpose. When he had been down himself with a new and bright helmet on, he had seen quantities of fish swimming round it. Apparently anything bright attracted them.

Mr. HaLPIN said it was easy to get rid of any difficulty connected with fish coming in the way of the electric light, by ejecting a small quantity of paraffin oil into the water round the lamp, which at once drove the fish away. 
Mr. E. B. Martex said that in South Staffordshire he had several times made the author's diving apparatus useful for liberating old lifts, in shafts where they could not be disentangled from above. The men went down to very great depths-say 110 feet; and it was a most remarkable thing how, even where they had to go down a most entangled shaft and in a strange pit, the men ventured down in total darkness, feeling their way about. One of the men even said he would rather have no light; and, although he had to go amongst all sorts of timber \&c., he felt his way carefully down, and came up again in a few hours after accomplishing all that he had to do.

Mr. Charles Hawkgley said that Mr. Gorman had omitted to explain one interesting point in the diving bell. In some cases accidents had occurred through the turning over of the bell, when allowed to rise to the surface: owing to accidental canting of the bell, the water ballast rushed to one side, and turned it over, and the men were drowned. In the bell in question provision was made to prevent such an accident; because the ballast chamber was divided by a horizontal partition, so that, supposing the bell rose suddenly and canted, the water below the partition would not rush to one side, but would be held in place by the partition. He did not wish to imply that the contrivance was an original one. It had been previously used in connection with torpedo work.* Again, in the Proceedings of the Institution of Civil Engineers, vol. xxxvii., p. 339, there was an account of Mr. B. B. Stoney's great diving-bell, by which the North Wall at Dublin was extended, and which was being used at the present day for lowering his 300-ton blocks of walling. That bell was 16 feet square at top and 20 feet square at bottom, and weighed $80 \frac{1}{2}$ tons; it had the same arrangoment as to the air lock, but not as to the water ballast.

Mr. Finedss said that in working in pits it was utterly impossible, although his apparatus was complete for breathing, to work without a light; and where the gases were so dense that the men could not breathe them, it was necessary to have some special kind of lamp. He

* See also Proceedings Inst. M. E., 1867, Plate 19, Fig. 22, and pages 94-5. 
exhibited a lamp (Plate 27) which he had designed for the purpose, and which he had frequently carried, when working in the Maudlin seam at Seaham. It was a modification of the lime light. The lower part A of the lamp (Fig. 20) contained the oxygen under a pressure of 16 atmospheres, while the hydrogen was supplied from methylated spirits of wine, contained in the cylinder $B$, to a burner $\mathrm{C}$, fed by two wicks. Between these wicks a stream of oxygen was made to plav through a small jet $\mathbf{D}$ upon a cylinder of lime $\mathbf{E}$, held on a stud placed to receive it. There was thus a jet of oxygen burning in an atmosphere of hydrogen, which he believed was a novelty in lamps. The sphere A was charged with oxygen, when required, through the valve $I$. The stream of oxygen was regulated by a jamb-screw valve $F$ attached to the oxygen chamber. The upper part or cover $G$ of the lamp was a double casing, and the annular space between the two casings was nearly filled with water. There were double glasses $\mathrm{HH}$, one in each casing, and the water circulated between them. The products of combustion escaped through a valve $J$ at the lower part of the casing into the annular space filled with water, through which they bubbled up, and finally escaped through an outlet valie $O$ at the top. A valve was placed here, merely in order to prevent any dirt from getting into the water and so obscuring the light; the lamp burned equally well with or without the valve. The cover was secured by a leather washer and screw joint, and the lamp was. carried by a handle $\mathrm{K}$. After the lamp had been burning about a quarter of an hour, about a quarter of an inch additional depth of water would be formed in the casing by the combustion of the hydrogen and oxygen. This was also a great element of safety, as it made a water sealed joint. The lamp had been used at the Seaham colliery with great success, and the men were frequently able to see to work at a distance of 40 yards from the lamp, which showed the power of the light. The lamp would burn in any explosive gases or under water. He had used it night and day for five weeks at the opening of the Maudlin seam, which was full of explosive gas. The lamp now exhibited, with a 7 -in. sphere, would burn four hours; and one with a 10-in. sphere would he thought burn twelve hours, but that would increase its weight from $12 \mathrm{lbs}$. up to 15 or $16 \mathrm{lbs}$. 
He might vo permitted to say further that, if the breathing apparatus and the lamps were kept ready at every colliery, they would often, he believed, be the means of saving human life and property. At the Killingworth colliery, mentioned by the author, one of the men who had been. rescued had since died from exhaustion; but the apparatus that was used there had to be obtained from another colliery at a considerable distance, and had it been on the spot he was certain that the men would all have been got out alive, and no deaths would have occurred subsequently.

Mr. Charies Cochrane said it would be interesting to know how the reservoir of the breathing apparatus could be promptly charged with oxygen, so as to ensure that there should be no mistake as to its use when required.

Mr. Fleuss said the vessel could be kept charged for any length of time, by using common precautions in shutting off the valve. It could be easily seen at any time whether the valve was properly shut, by putting a film of moisture across the hole, when in an instant it would be seen if gas was leaking even to the smallest extent, by the bubbling of the film. To ensure a sufficient supply of the oxygen gas, it might be carried in an iron store cylinder, containing 30 cubic feet under a pressure of 600 lbs. to the square inch. A connection could be made from this to the breathing apparatus by a flexible india-rubber tube capable of standing the pressure; and with the aid of a pressure gange the reservoir could be charged to 240 lbs. or $260 \mathrm{lbs}$. pressure. Apart from that plan, it was very easy to make oxygen gas. All the theatres made it for their lime lights, and he himself left a complete set of gear for making it at the Seaham colliery; after working there for five weeks. It comprised a mercury bottle converted into a retort, with a pipe attached. There were two purifying vessels containing simply water-changed as often as was desired-to wash the chlorine out of the gas. There should be two or three bags to hold the gas as it was made : and in twenty minutes you could get off enough gas to charge one breathing machine, and in a few minutes longer enough to charge several more. Small 
handy compressing pumps were made to force the oxygen into the breathing machines or lamps. He had used such an apparatus all the time he was at Seaham, keeping two or three store bottles in reserve, in case of the pump breaking down, which it did once or twice from the great strain put on it, and from the firing of the leathers. They were working day and night with six lamps and six breathing machines; and these were constantly being brought up, refilled, and taken down again.

Mr. JeReman Head asked what was the cost of the whole apparatus, and whether there was any difficulty in getting the miners to use it.

Mr. Fleugs said, roughly speaking, the cost was $£ 18$ for the breathing machine, and $£ 1310 s$. for the lamp. There was no difficulty in getting the men to use the apparatus, except when they first had to put on the mask, and go into a pit the conditions of which they knew nothing about, and where there were gases that would kill them if unprotected; then they might perhaps feel a little nerrous. At Seaham they put up a wooden building at bauk, filled with sulphur fumes, so as to give the men two or three days' practice. He found plenty of volunteers for that, but for going down the pit itself the numbers were considerably reduced. There were however half "dozen first-class men who weat. in fearlessly, and were ready at any time. Some of these men afterwards went down the Killing worth colliery, and were the means of rescuing several lives.

The President said that he was glad to inform the meeting that Lieut. Stanley Dean-Pitt, R.N., had been good enough to be present on this occasion, having come expressly from Portsmouth, to give them the benefit of his experience in the diving operations carried on at the wreck of the Doterel.

Lifur. Dean-PITT said all subjẹcts connected with engineering were of great interest to naval officers. At the present day it was absolutely necessary for a naval officer to know something about 
engineering; and he might mention, as a proof of the change which was going on in the service, the pleasure they had had the other day in hailing the appointment as a Lord Commissioner of the Admiralty of that eminent and practical engineer Mr. George Rendel. Submarino engineering had always been to himself a subject of keen interest, and some years ago he was fortunate enough to have the opportunity of practically learning to dive. This had proved of great service to him lately, when the terrible disaster occurred at Sandy Point, Magellan Straits, in which H.M.S. Doterel was totally destroyed, and 140 men and officers killed. H.M.S. Garnet, to which he belonged, was then on the South-East coast of America, and received telegraphic order's from the Admiralty to proceed at once to the scene of the accident. On arrival there, after $\Omega$ few preliminary matters had been settled, they went to work. The wreck was lying in 12 fathoms, or $72 \mathrm{ft}$; and, the water being comparatively clear, George Hunt, an artificer diver, and himself were able to make a very careful survey of every part of the wreck.

He would not dwell upon the many awful sights that met their view; but some idea might be formed of how things were when he stated that, out of the 140 men who were killed, there were only twenty whole bodies, the remainder being in pieces. Of the whole bodies one was that of his old friend and shipmate Lient. Creagh, who was sitting in an arm-chair under the poop just as if he were asleep, and without a mark on him-perfectly uninjured, as far as outward appearances went. The ensign was half-mast high, looking as if it was mourning for the killed; and he hoisted it up again, as he did not care to go about his work under a half-mast flag. The system of their work was this. They commenced at daylight, which was at 7.30 in the morning, and worked until dark, between 4.30 and 5 . They generally used to stop for an hour in the middle of the day, at 12 o'clock. They worked under water two to three hours at a spell, and then came up for ten minutes or a quarter of an hour, and went down again. They worked every day for five weeks, Sundays included. On the average four men, namely three divers and himself, were at work all the time; and they recovered the whole of the ship's armament, including six heary guns and two 
machine guns, her anchors, chain cables, spars, yards, and a variety of other things which it was needless to enumerate. After they had been at work some time, with a good deal of difficulty the artificer diver and himself succeeded in reaching the boilers; they were able to make a careful examination of them, and thus to decide that most important question, whether they had exploded or not. They were intact. They also entered and very carefully examined the bunkers; and there had never been any doubt in their minds that these also had never exploded.

He desired to congratulate the author upon the great efficiency of the apparatus described in the paper. If it had not beon most perfect, he himself should not have had the pleasure of being present on this occasion; because one day, when they were looking after the boilers, he was standing on some wreckage, when it gave way, and he was thrown head downwards into a hole, where he was firmly fixed and perfectly helpless. As far as he knew, he might have been there still; but the artificer diver saw him and came at once to his help. He could not get to him, but he paid a rope down into his hands; and he (Lieut. Dean-Pitt) then twisted it round the neck of his heimet, and after some minutes the diver managed to haul him up feet foremost, the apparatus remaining uninjured. He thought that, if anything ever proved the efficiency of the apparatus, it was that incident: at least it proved it to him.

With regard to the open helmet, described p. 182, he was very thankful it had been so much improved upon; for if he had been wearing an open helmet on the occasion mentioned, he must undoubtedly have been drowned. He thought the fact that he himself and three men had worked continuously for five weeks at a depth of 12 fathoms, on a broken wreck covered with debris of every description, and in intensely cold water, without a single accident of a serious nature, was a conclusive proof of the very great efficiency and perfection of the apparatus in question. He was very glad to hear that the author had tested the submarine electric light, which would be undoubtedly a very valuable help in diving operations. He should like to hear also whether the author had tested the telephone for the use of divers; because at the wreck of the Doterel, where the water was 
intensely cold, there being over a foot of ice on shore, it was quite impossible to do such a delicate thing as to write legibly upon a slate. They could read what was sent down to them, but they could never answer, or only rarely, in writing. If they had had a telephone, it would have been invaluable, and would have saved a great deal of time and Iabour.

Mr. WM. ANDerson asked what temperature there was inside the diving dress. He imagined it must be tolerably high, if they could remain long under water so cold. He also wished to know what degree of light there was at the depth they worked at, and how far they could see.

Lreut. Dean-Pirt said the temperature inside the dress depended entirely upon how they were working. If they worked hard, the temperature got very high; and they sometimes had to rest a few minutes to get cool. But what they suffered from chiefly was the intense cold to their hands. With regard to the light, the water was very clear indeed, clearer than was usual close to the land; and they could very fairly distinguish what a thing was at a distance of 7 or 8 feet, though they could not see its parts distinetly.

Mr. Gorman, in reply, said Mr. Halpin had suggested a slight improvement in the knobs for screwing up the front eye-glass. He thanked Mr. Halpin for the suggestion, which would be of great nssistance in screwing up the glass when the hand was cold. He had tried fixing the front eye or screw leas by a hinge joint, but had found it did not work satisfactorily. Another gentleman, Mr. Schönheyder; had suggested to him privately the arranging of the glass with a segment like the neck screw, so that it could be unscrewed by one-eighth of a turn. They had tried that, but the divers objected to it; because when a man was in a confined position, for instance between decks discharging cargo, if anything happened to strike the glass as ho was moving, it might possibly get unscrewed by the one-eighth of a turn, and drop out, and then the man would be drowned. Perhaps however, where men were 
simply laying concrete blocks, or in places free from danger, the plan might be useful.

Mr. Cochrane had kindly referred to the efforts made in sending off some men to his pits about ten days back. They had been sent off in two hours after receiving the telegram, and in twenty-four hours they had completed the work allotted to them, thereby preventing a serious disaster. They had done the same thing on several occasions, for Mr. Marten and others. It was true that the men preferred to work without artificial light. They became actually like blind men; the sense of feeling became very acute, and working from day to day as they did they became wonderfully quick at the work they had to perform. In the case of the wreck of the s.s. Caledonian the men actually took the engines to pieces under water, and sent them up; also the boilers; and that was done in total darkness.

With regard to the air-lock diving bell, Mr. Stoney's great bell, used in 1871, was somewhat different in construction from the one now exhibited, being of cast-iron, in sections bolted together; whereas the bell represented by the model was made of wrought-iron, the upper chamber of $\frac{3}{8}$ in. and the lower of $\frac{1}{2}$ in, plate. It was also provided with a water-ballast chamber, as described by Mr. Hawksley. But he was indebted to Mr. Stoney for very valuable hints, having been in correspondence with him during the time he was constructing the bell for Barbadoes.

With reference to the uses of the diving apparatus at the present time, the Admiralty now attached so much importance to the subject that they had established two classes for training divers, one at Portsmouth and the other at Devonport, and they had annually from eighty to ninety divers trained for the service. The Royal Engineers also had classes formed, at Chatham; the men were trained in the Medway, and they also went to dive off Sheerness, where they got into deep water. The Royal Engineer officers were likewise urged to dive. In the Navy the officers could learn diving if they chose to do so; and they had just beard an instance of the value of that system, because Lient. Dean-Pitt's cxamination of the wreck was most valuable to the Admiralty when he was summoned home to give evidence at the Court Martial. Again the 
value of the sponge imported into this country each year amounted to $£ 90,000$, and that was mostly obtained by helmet divers. Lately the pearl fisheries in the Torres Straits had also become very extensive; a schooner had arrived home a short time ago with a very valuable cargo which had been fished up in six weeks, and which realised $£ 8,000$. There were now a number of vessels fitted out for that purpose. Altogether therefore the apparatus was being developed in other directions besides harbour worlss and wrecks, where it was absolutely necessary. Actual experience had proved the necessity of having one or two divers on board each of our war ships; and on board our large merchant steamers they would be equally useful. The Telegraph Construction Co., as also Messra. Siemons, carried divers on board their cable ships. Much detention and loss of time and money might be prevented, and even the loss of many valuable ships and lives, if a diver were always at hand to lend his services when required. Feeling the necessity for this, he had brought out a small portable diving apparatus, occupying little room, and costing only $£ 40$; and at his works he had a large diving tank 12 feet deep, where steamship owners could have one of their engineers or ship carpenters trained. He might mention a case in point. One of his men was proceeding to the Sydney Exhibition on board the Poonals $P$. and $\mathbf{O}$. steamer, when her propeller became loose on the shaft while steaming against a gale in the Red Sea. The necessary repairs were dono by the diver, and the voyage was resumed, preventing considerable loss of time and money.

With regard to the telephone, he had been carrying out a number of experiments with that instrument, and had made it very perfect. At present, if two divers under water placed their helmets together, they could hear one another converse. But with the new instrument, if two divers placed their helmets together, the men at the surfaco could hear what the divers were talking about. He hoped to exhibit this on a future occasion. As the services of divers were now required for so many various operations, it was necessary to equip the men with every possible contrivance, so that they could work without danger, and with such confidence as should enable them to do credit to themselves and give satisfaction to their employers. 
Fig. 1. Kleingert's Dress.

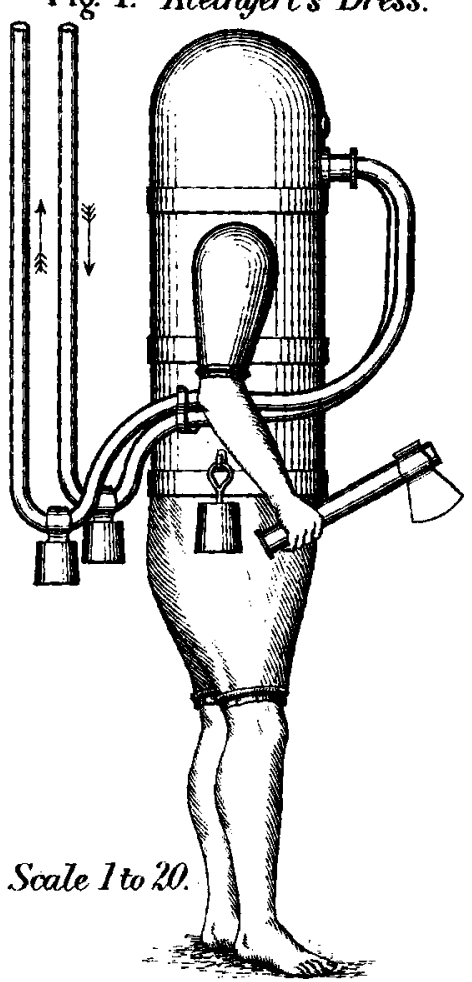

DIVING APPLIANCES.

Rennie's Diving Bell. Fia. 3.

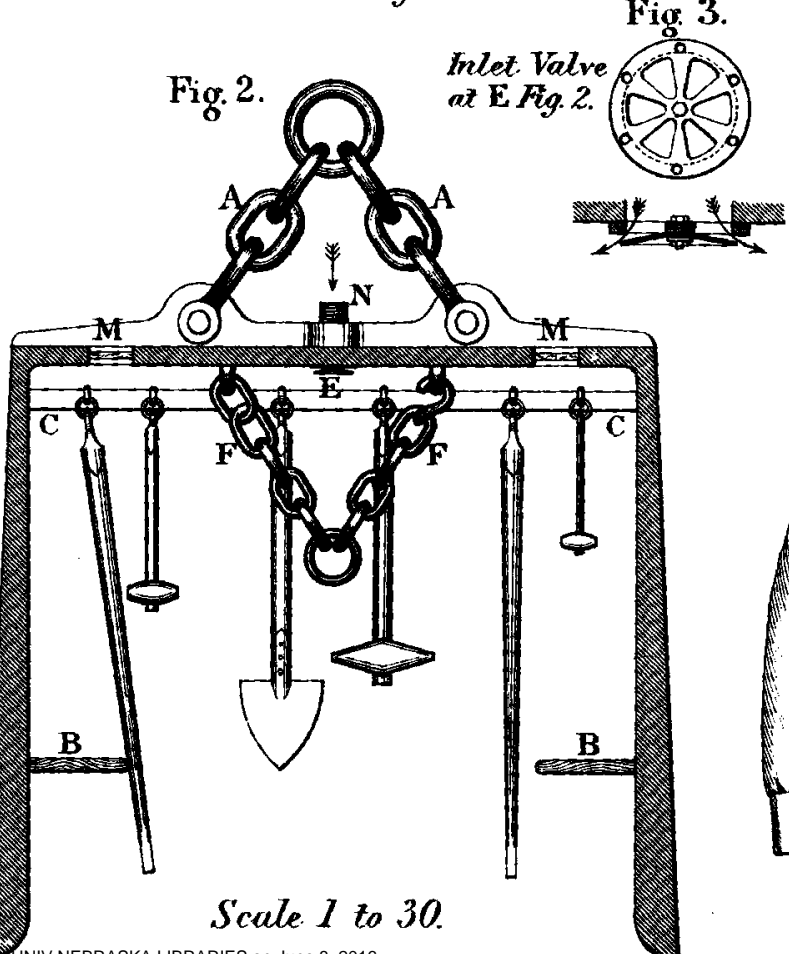

Plate 22.

Fig 4.

Siebe's Open Diving Dress.

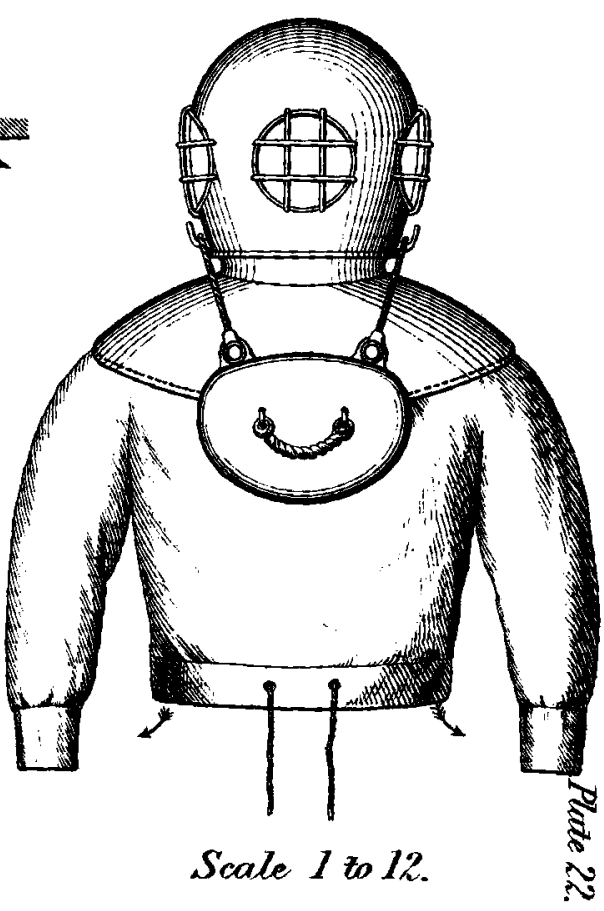


DIVING APPLIANCES.

Fig. 5.

Siebes Close Helmet.

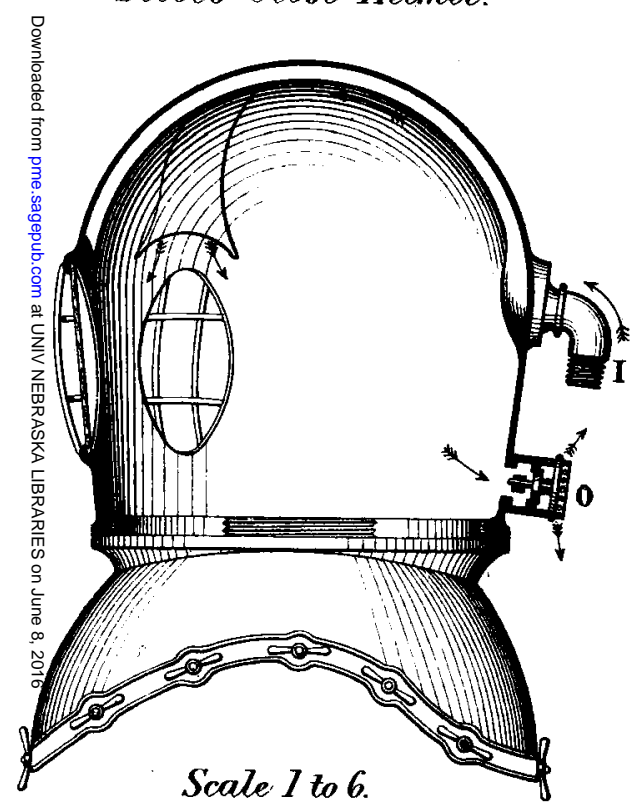

(Proceedings Inst. M. E. 1882.)
Fig 8.

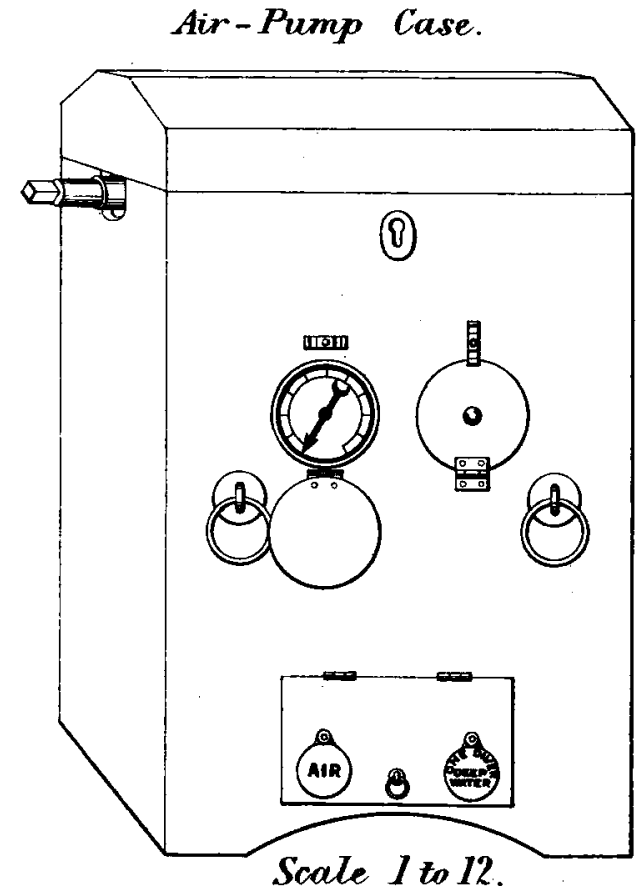

Mate 23.

Fig. 11.

Plan of Air-Valve Lever.

Scale 1 to 8.

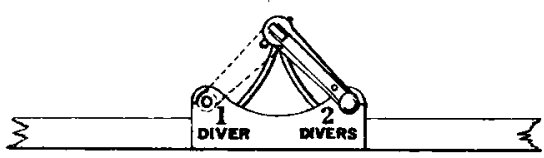

Diagram of Air-distributing Valve. Fig. 9. Fig: 10.

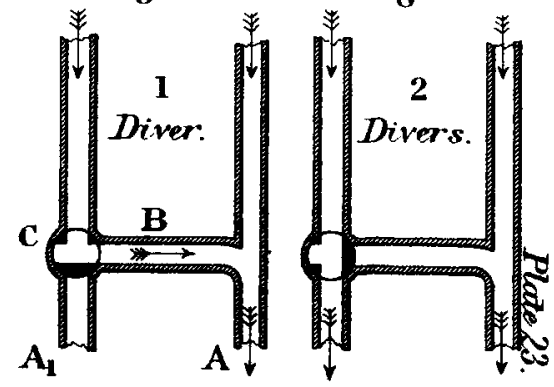




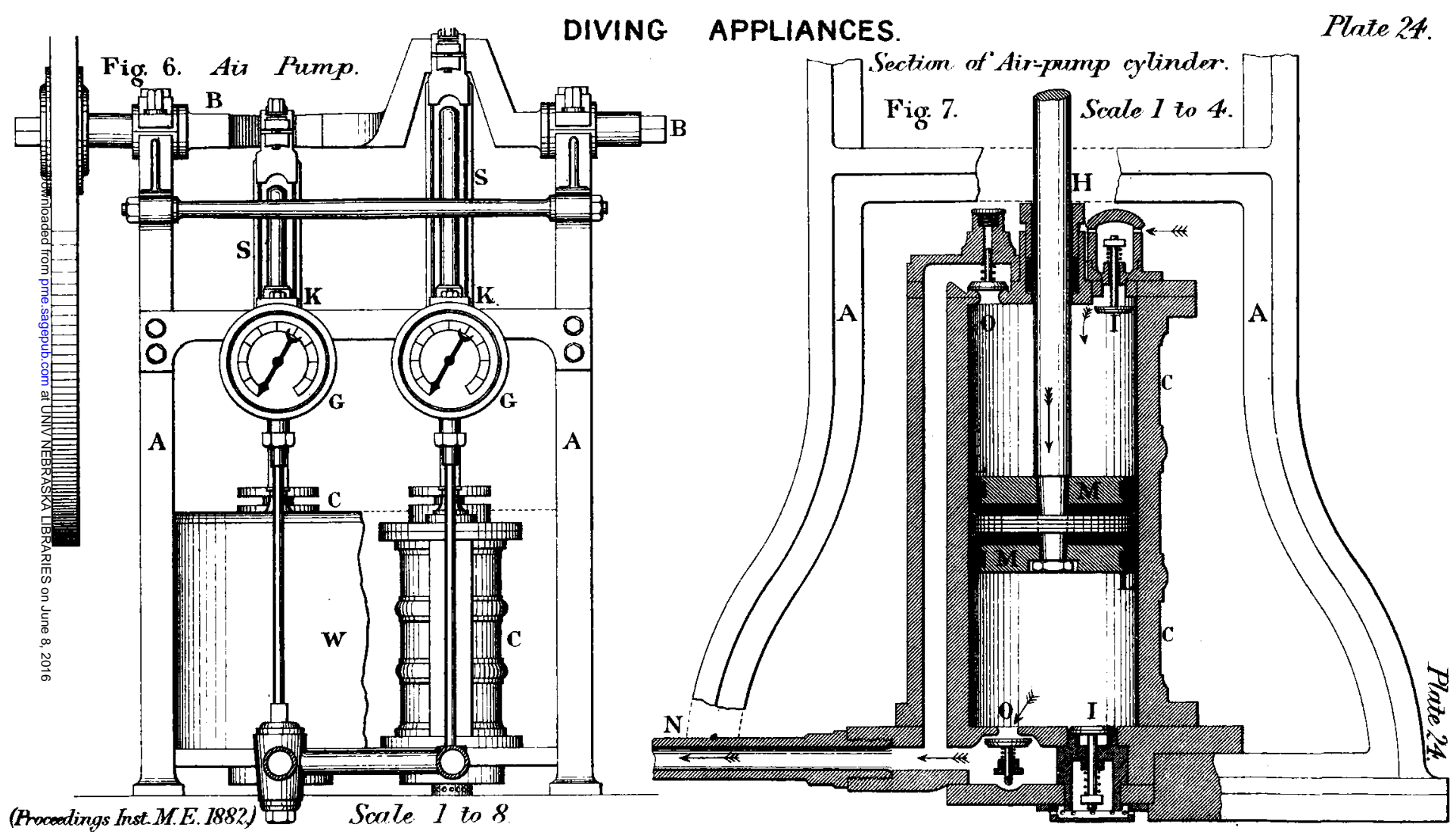


DIVING APPLIANCES.

Improved Helmet.

Fig. 12. Elevation.

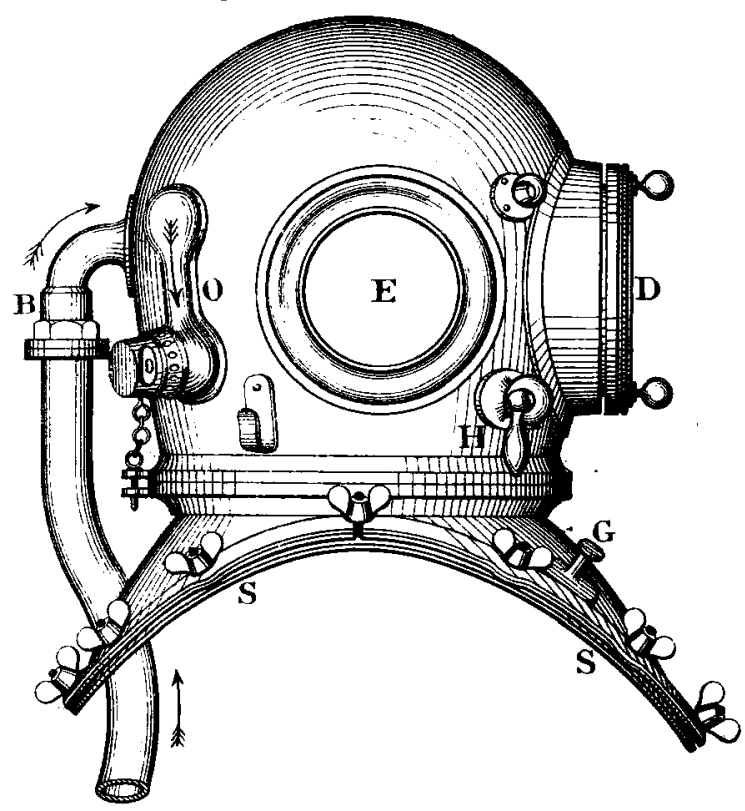

(Proceedings Irest. M. E. 1882.)
Fig. 13. Section.

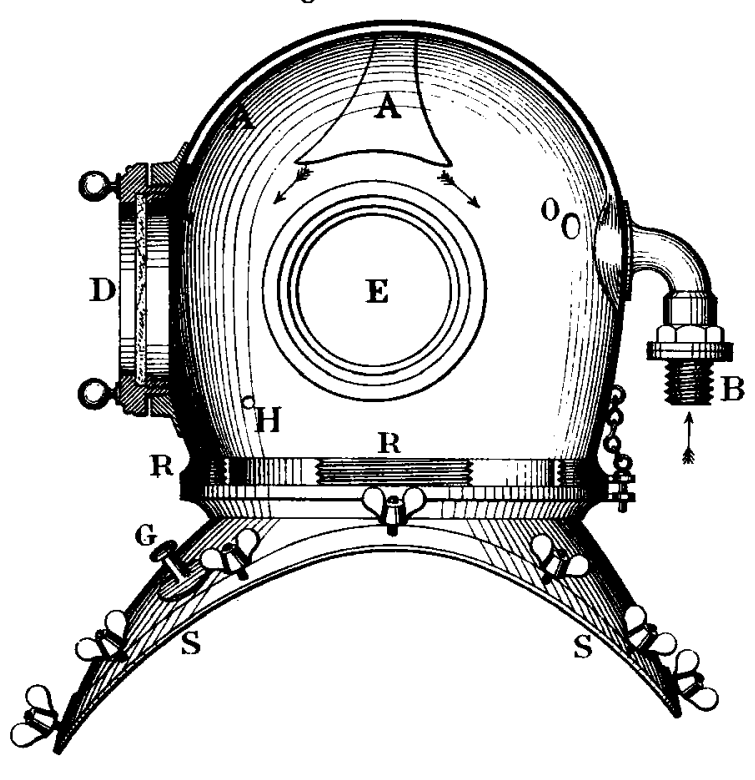

Scale 1 to 6.
Plate 25.

Fig: 14.

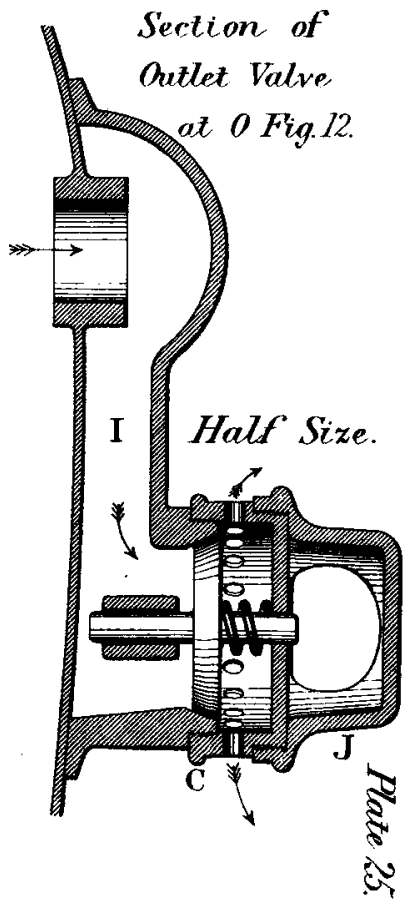


DIVING APPLIANCES.

Fleuss' Breathing Apparatus.

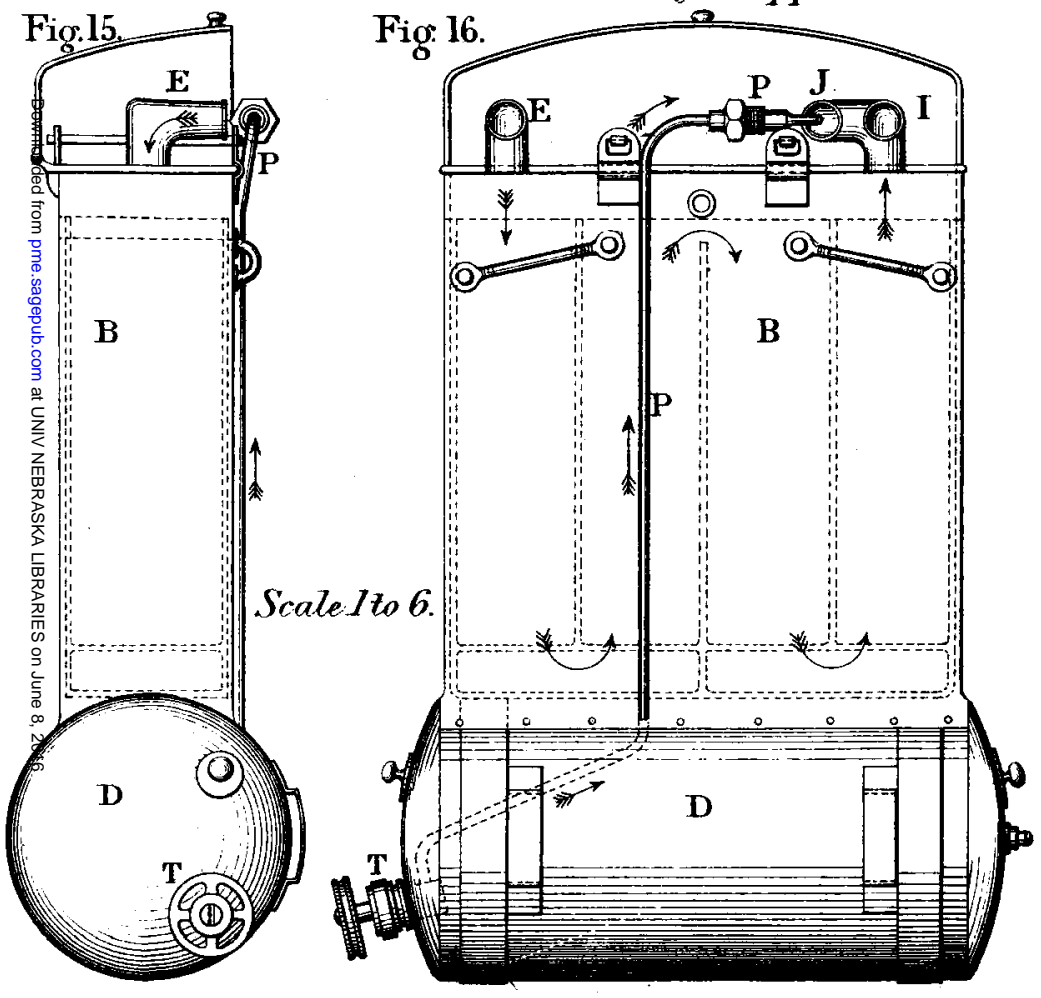

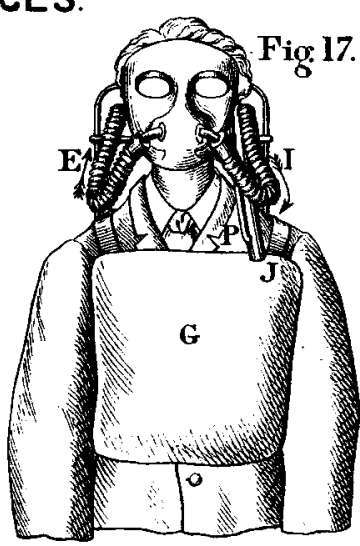

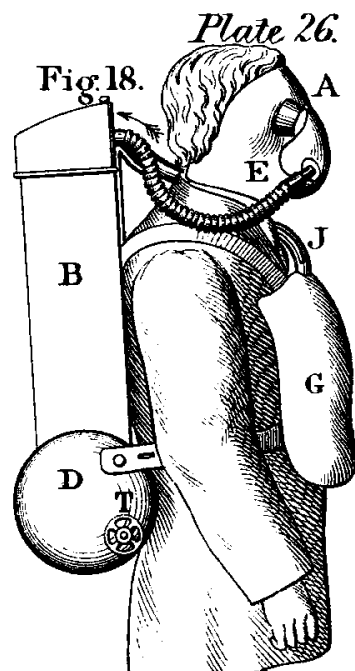

Fig: 19. Valve at T Fig.16.
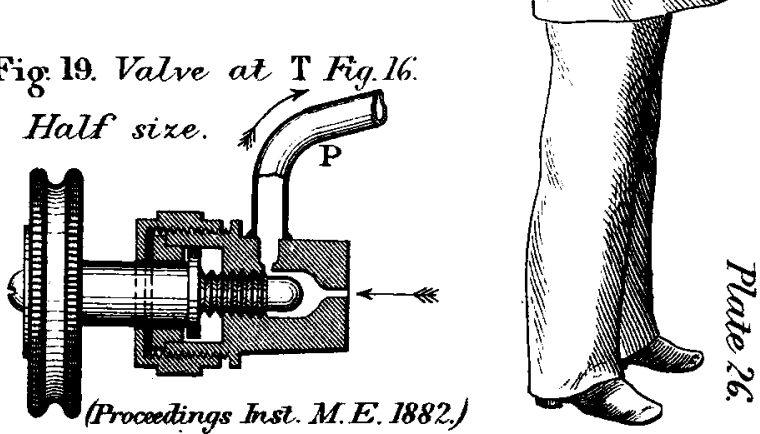


\section{DIVING APPLIANCES. Plaze 27.}

oxy-hydrogen Safety-Lamp.

Fig: 20.

Section of Lamp.

one third full size.

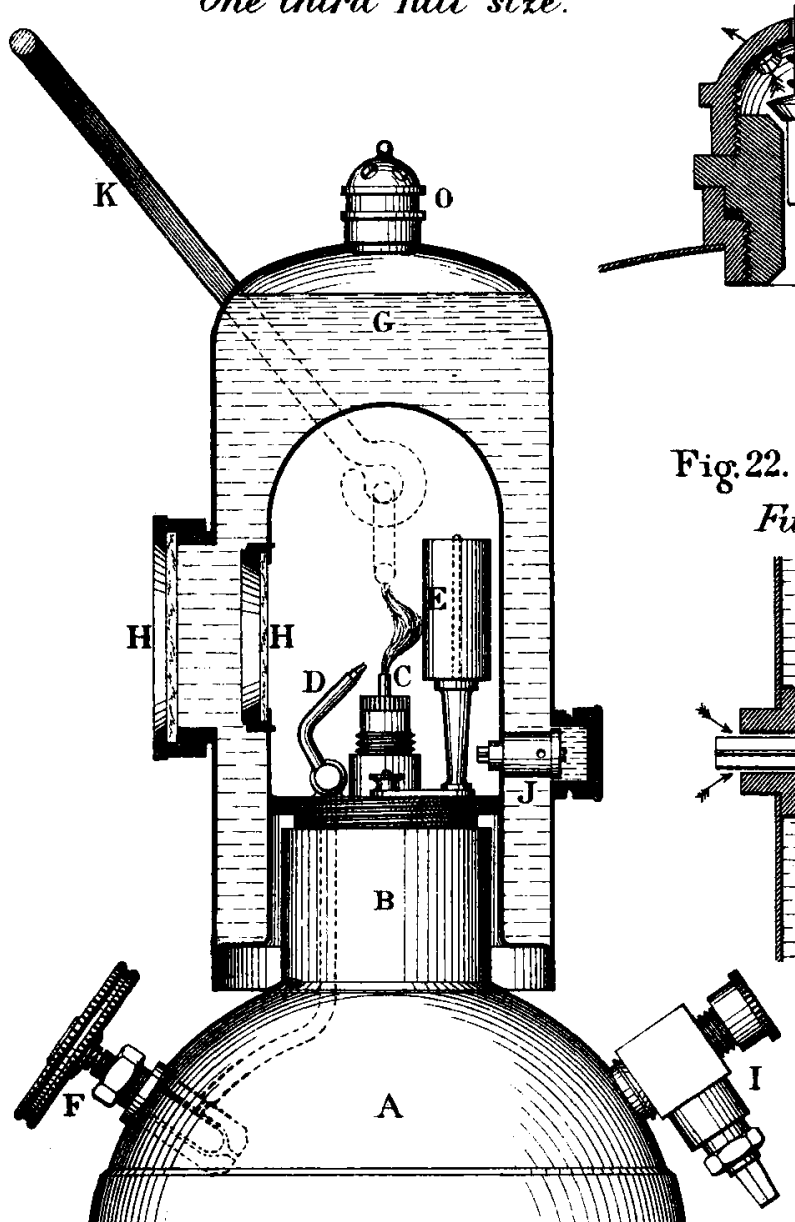

Full size.

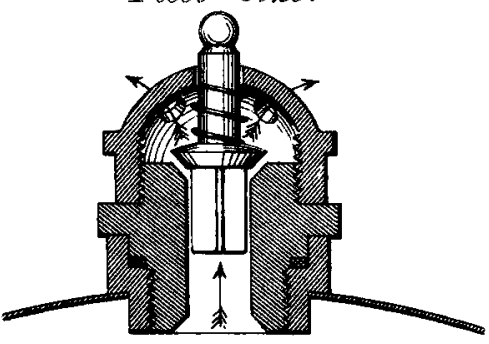

Fig. 22. Valve at J Fig. 20 .

Full size.

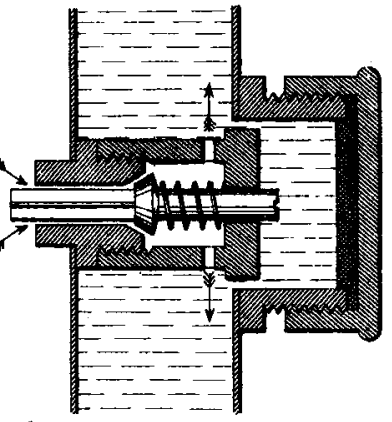

